\title{
Simulation of the Structure of Bond Issuer's Obligations Fulfillment: A Case of Sub-Federal Bonds
}

\author{
Yulia V. Semernina* ${ }^{[0000-0003-2098-795 X]}$, Alla V. Yakunina ${ }^{[0000-0002-3747-3982]}$, \\ Elena A. Ermakova ${ }^{[0000-0002-6454-6745]}$, Sergey V. Yakunin ${ }^{[0000-0003-0960-0021]}$, \\ Elena V. Zhegalova ${ }^{[0000-0003-0102-8868]}$, Eugene A. Korobov ${ }^{[0000-0001-7198-5941]}$ \\ *Saratov Socio-Economic Institute (branch of Plekhanov Russian University of Economics), Saratov, Russian Federation \\ *ysemernina@yandex.ru, alla.yackunina@yandex.ru, eae13@mail.ru,ysw@yandex.ru \\ Samara State University of Economics, Samara, Russian Federation \\ zhegalova@rambler.ru Saratov State University,Saratov, Russian Federation \\ korobovea@yandex.ru
}

\begin{abstract}
Depreciable bonds issues can significantly expand the issuers' abilities to manage public debt. The purpose of the study is to suggest possible options for a model for fulfilling obligations by issuers of depreciable sub-federal bonds. The study was conducted using a discrete grouping constructed according to the criterion of the bonds face value repayment number. We propose a set of indicators to assess the issuers' possibilities to place depreciable sub-federal bonds in the Russian market. Our analyses showed that, during the period under review, the probability of successful depreciable bond issues placement in the sub-federal segment remained at a high level for bond issues with a nominal value of no more than 30.0 billion rubles and a maturity of no more than 3650 days. Deterioration of the bond market environment did not lead to significant changes in the structure of the bond issuers' obligations fulfillment. The most common was a model involving four repayments of the depreciable bonds nominal value.

Index Terms-depreciable bonds, sub-federal bonds, simulation of bond issuance, structure of the bond issuers' obligations fulfillment, $b$ ond market
\end{abstract}

\section{INTRODUCTION}

For a long time, the unconditional predominance of onetime repayment bond issues was a distinctive feature of the domestic bond market. This bond obligations fulfillment structure does not imply bond's nominal value depreciation and is very attractive for those categories of investors who prefer to own bonds until its maturity and practice short-term financing u sing b onds a s liquid collateral.

From the investors' point of view the described bond obligations fulfillment structure significantly increases the likelihood of the bond issue default risk realization. On the other hand, the structure is not always optimal for bond issuers, especially for issuers of sub-federal bonds which are subjects for a few legislative restrictions.

Nevertheless, until now, the depreciable bonds issues have received almost no attention in the specialized scientific literature, although such issues can significantly e xpand the issuers' abilities to manage public debt. A lack of research in this area results in the situation that many bond issuers, especially in the of government and corporate bonds segments, are primarily guided by the historical stereotype regarding the bond obligations fulfillment structure ignoring the fact that the one-time repayment bond issue does not always provide the best conditions for raising capital.

The purpose of our study is to assess the potential for issuers to place depreciable bonds on the Russian market and suggest, based on retrospective data, possible options for a model for fulfilling obligations by bond issuers (using the sub-federal bond segment as the example).

\section{LiterATURE REVIEW}

Using bonds to raise a firm's capital or to finance a deficit is a popular topic in the economics and finance literature. In his famous book, F. Fabozzi presented his "applied approach" to understand bond markets and to form relative strategies [1].

Quite a lot of papers are devoted to different aspects of bonds issued by the national and sub-national governments. Boubaker S., Nguyen D. K., Piljak V., and Savvides A. investigate the effect of financial development on government bond returns in developed and emerging markets under different market conditions [2]. A study of Zaremba A. and Schabek T. is focused on seasonality in government bond returns [3]. Valseth S. is exploring price discovery in government bond markets using Norwegian data including trades from both tiers of the market and dealer identities [4]. Paper of Sola S. and Palomba G. examines the determinants of sub-national governments' risk premia in fiscal federations using secondary market data for the USA, Canada, Australia and Germany [5].

However theoretical and methodological issues involving a detailed analysis of the structure of bond issuers' obligations fulfillment have remained beyond the scope of research up to now. When considering these issues, the prevailing is a stating approach, in which researchers use a concise description of bond groups built on the nature of nominal value repayment as the main grouping feature; and then the groups are considered in the framework of a wide variety of bond classifications (such an approach is used in research of A. V. Yakunina, Yu. V. Semernina [6], E. V. Solovova [7], P. A. Lashevsky [8], A. A. Shcherbakov [9], A. N. Kiryushkina [10]). A distinctive feature of the above scientific position is the initial 
$n$ - total number of outstanding bond issues in the target segment;

assumption that any issuer "by default" has the ability to place depreciable bonds. In this approach, at least two distinctive features associated with investing in depreciable bonds are ignored: firstly, the acquisition of such securities leads to an increase in the proceeds reinvesting risk and, secondly, as bond issues amortize, their market liquidity is decreasing, and quite significantly.

A somewhat different point of view on this issue is presented in the articles of scientists who consider bonds, including depreciable bonds, in the context of the investment portfolios construction and its subsequent management (see, for example, N. F. Korobov and A. A. Beloglazov [11], A. A. Ponomarev [12], L. V. Sturikova and A. A. Ayupov [13], O. I. Rekundal [14], I. R. Baybekov [15]). These authors consider the repayment of the bond issues nominal value (full or partial) as an objective reason for changing the structure of the investment portfolio, noting that the acquisition of depreciable bonds and their ownership leads to an increase in the frequency of reviewing the structure of the investment portfolio. However, in the vast majority of cases, they consider the formation of bond portfolios only through purchasing bonds on the secondary market, i.e. the situation when the issuer has already placed depreciable bonds is analyzed.

\section{METHODS}

The simulation method is used to assess the issuers' possibilities to place depreciable bonds on the Russian market. The application of this method involves preliminary segmentation of the domestic bond market (differentiating between government, subfederal, municipal and corporate bonds as independent segments), selection of the target market segment (the subfederal bonds segment is used as such in the study) and a consistent analysis of the impact of the placement of each bond issue in target segment on its overall structure. Thus, during the simulation, each bonds placement in the target segment is recognized as a statistically significant event, simultaneously affecting both the possibility of placing depreciable bonds and the options for the model of fulfilling obligations by bond issuers within the analyzed segment.

The application of the simulation method in the Russian bond market is highly effective due to the fact that the vast majority of events occurring on it (placement of a new bond issue, partial repayment of the outstanding bond issue's face value, full repayment of the bond issue's face value) are discrete and at the same time characterized by a high level of predictability.

To assess the issuers' possibilities to place depreciable bonds in the Russian market, it is proposed to use the following set of criteria calculated for the target segment of the national bond market:

1) share of depreciable bond issues out of the total number of outstanding bond issues $\left(f_{Q}\right)$ :

$$
f_{Q}=\frac{n_{A}}{n} \cdot 100 \% \text {, }
$$

where $n_{A}-$ the number of circulating depreciable bond issues in the target segment;
2) share of the outstanding face value of depreciable bond issues out of the total face value of outstanding bond

$$
f_{N}=\frac{F V_{A}}{F V} \cdot 100 \%
$$

where $F V_{A}$ - outstanding face value of depreciable bond issues in the target segment;

$F V$ - total face value of outstanding bond issues in the target segment;

3) maximum initial face value of circulating depreciable bond issue in the target segment $\left(F V_{A_{\max }}\right)$;

4) maximum circulation period of depreciable bond issue in the target segment $\left(M_{A_{\max }}\right)$.

All of these indicators are momentary (calculated on a specific date based on actual data on the target segment of the bond market) and are determined for the target segment with respect to circulating (outstanding) bond issues (regardless of the remaining time before maturity), denominated in one currency (regardless of what currency - national or foreign is used for denomination)

Placement of depreciable bond issues by issuers is recognized as possible subject to the following conditions hold simultaneously:

1) $f_{Q}>\delta_{Q}$, which uses the formula:

$$
\delta_{Q}=\sqrt{f_{Q}\left(1-f_{Q}\right)},
$$

where $\delta_{Q}$ - standard deviation of the share of depreciable bond issues it the total number of outstanding bond issues;

2) $f_{N}>\delta_{N}$, which uses the formula:

$$
\delta_{N}=\sqrt{f_{N}\left(1-f_{N}\right)},
$$

where $\delta_{N}-$ standard deviation of the share of the outstanding face value of depreciable bond issues in the total face value of bond issues;

3) $F V_{A_{P I}}<F V_{A_{\max }}$, where $F V_{A_{P I}}$ - nominal volume of the issuer's planned depreciable bond issue;

4) $M_{A_{P I}}<M_{A_{\max }}$, where $M_{A_{P I}}$ - maturity period of the issuer's planned depreciable bond issue.

These inequalities are interpreted as follows: in the target segment of the bond market, the actual share of depreciable bonds both in the total number of outstanding bond issues and in the total face value of outstanding bond issues should exceed the standard deviation of the corresponding relative indicator (criteria for the materiality of the share's size), while planned placement parameters of the depreciable bond issue should not exceed the maximum parameters of depreciable bond issues presented in this segment (comparison criteria with tradable bond issues).

Placement of a depreciable bond issue by the issuer is recognized to be possible while meeting all of the above inequalities (very high probability of placing a depreciable bond issue); issues $\left(f_{N}\right)$ : 
all, in the oil market) Among the relevant domestic factors, we should mention the tightening of monetary policy by the Bank of Russia, the national currency depreciation, rising inflation expectations, and the reductions of non-residents' ruble debt obligations positions (most clearly this trend is evident in the segment of government bonds). Deterioration of market conditions leads to a decrease in the level of investors' activity in the bond market, and contributes to the formation of a "selective approach" to the choice of bond issues to be included in the investment portfolio, especially for the initial bonds issues.

Thus, as of January 1, 2018, 121 bond issues were circulating in the subfederal bonds segment, while on January 1,2019 , the number of circulating bond issues was reduced to 115 However, the structure of the analyzed segment of the Russian bond market did not undergo drastic changes (Table I).

The calculation results shown in Table 1 clearly indicate the absolute dominance of depreciable bonds in the target segment, and according to the results of the analyzed period, the proportion of depreciable bonds in the general structure of the target segment slightly increased (from $91.74 \%$ to $93.04 \%$ ), which was due to different rates of reduction in the number of issues of depreciable and non-depreciable bonds (a decrease of 4 bond issues or $3.60 \%$ of the total versus a decrease of 2 issues or $20.00 \%$ of the total numbers, respectively)

At the same time, the share of depreciable bond issues in the total number of circulating bond issues exceeded the value of the corresponding standard deviation both at the beginning $\left(\delta_{Q_{2018}}=27.53 \%\right)$, and at the end of this period $\left(\delta_{Q_{2019}}=25.44 \%\right)$, i.e. the first criterion of share's size materiality was met. Nevertheless, a comparison of the size of the depreciable bond issues' share in the total number of circulating bond issues with the mean square deviation allows us to conclude that this ratio has grown (from 3.33 to 3.66), which indicates that the probability of successful placement of depreciable bond issues by issuers has increased in the target segment

The essentially similar conclusions regarding the prospects for issuers to place depreciable bonds in the target segment can be made on the basis of an analysis of the structure by the face value of bonds, and this criterion shows a more significant increase in the depreciable bonds share in the target bond market segment (increase from $79.94 \%$ to $88.73 \%$ ) (Table II).

The result obtained is largely due to the opposite dynamics of the depreciable and non-depreciable bonds sub-segments: by the end of 2018, the depreciable bonds sub-segment increased by $1.79 \%$, while the non-depreciable bonds segment declined sharply - by $48.46 \%$ at once. The latter was due to the redemption in 2018 of two non-depreciable bonds issues, which had a significant face value: Moscow-25068-ob (face value - 40.0 billion rubles; maturity date - September 27 , 2018) and Moscow-27066-ob (face value - 30.0 billion rubles; maturity date - November 23, 2018)

It should be noted that the second materiality criterion of the share size was met during the entire analyzed period. By level of price volatility in the commodity markets (first of 
TABLE I

SUBFEDERAL BOND SEGMENT STRUCTURE BY THE NUMBER OF OUTSTANDING BOND ISSUES

\begin{tabular}{ccccc}
\hline & $\begin{array}{c}\text { At January 1, } \\
2018\end{array}$ & \multicolumn{2}{c}{$\begin{array}{c}\text { At January 1, } \\
2019\end{array}$} \\
\hline Type of bonds & $\begin{array}{c}\text { The number } \\
\text { of bond } \\
\text { issues, pcs }\end{array}$ & $\begin{array}{c}\text { Share of bond } \\
\text { issues in } \\
\text { total quantity, } \%\end{array}$ & $\begin{array}{c}\text { The number } \\
\text { of bond } \\
\text { issues, pcs }\end{array}$ & $\begin{array}{c}\text { Share of bond } \\
\text { issues in }\end{array}$ \\
total quantity, \%
\end{tabular}

TABLE II

THE STRUCTURE OF THE SUBFEDERAL BONDS SEGMENT AT FACE VALUE OF CIRCULATING BOND ISSUES

\begin{tabular}{|c|c|c|c|c|}
\hline & \multicolumn{2}{|c|}{$\begin{array}{c}\text { At January } 1, \\
2018\end{array}$} & \multicolumn{2}{|c|}{$\begin{array}{c}\text { At January } 1, \\
2019\end{array}$} \\
\hline Type of bonds & $\begin{array}{l}\text { Nominal value } \\
\text { of bond issues, } \\
\text { billion rubles }\end{array}$ & $\begin{array}{l}\text { Share of bond } \\
\text { issues in the total } \\
\text { face value, } \%\end{array}$ & $\begin{array}{c}\text { Nominal value } \\
\text { of bond issues, } \\
\text { billion rubles }\end{array}$ & $\begin{array}{l}\text { Share of bond } \\
\text { issues in the total } \\
\text { face value, } \%\end{array}$ \\
\hline Depreciable bonds & 575.661 & 79.94 & 585.951 & 88.73 \\
\hline Non-depreciable bonds & 144.450 & 20.06 & 74.450 & 11.27 \\
\hline Total & 720.111 & 100.00 & 660.401 & 100.00 \\
\hline
\end{tabular}

the end of the period there was a significant decrease in the standard deviation of the share of the depreciable bond issues' outstanding face value in the total face value of circulating bond issues $\left(\delta_{F V_{2018}}=40.04 \%, \delta_{F V_{2019}}=31.36 \%\right)$, and the ratio of the depreciable bonds share (at face value) to its value increased from 2.00 to 2.81 (in other words, compliance with the second inequality suggests that the likelihood of successful placement of the depreciable bond issues has increased for issuers)

As for the maximum initial nominal volume of the issue and the maximum circulation period of depreciable bonds in the subfederal segment, during the whole analyzed period the value of the first indicator was 30.0 billion rubles (St. Petersburg-2-35001-o (placement date - December 6 2017; maturity date - May 28, 2025)), and the second indicator - 3650 days (Udmurt Republic-35002-o (placement date September 21, 2016; maturity date - September 19, 2026))

Thus, we can conclude that during the period under review, the placement of sub-federal bonds issues of no more than 30.0 billion rubles in nominal value and of no more than 3650 days of maturity had a high probability of successful placement for an issuer.

A study of the structure of depreciable bonds issuers' obligations fulfillment during the reporting period was conducted using a discrete grouping constructed according to the criterion of the bonds face value repayments number $\left(C_{A}\right)$. For each interval obtained, we calculated the average value of the depreciable bond issue repayment's uniformity coefficients both at the face value and with respect to periods between the face value portions' repayments (simple arithmetic average formula was used for calculating the average values??of these coefficients).

As of January 1, 2018, in the depreciable bonds sub-segment of the sub-federal bonds segment, there were bond issues characterized by a significant variation in the number of bonds face value repayments: the minimum value of this indicator was 2 , the maximum was 10 (Table III).

The data presented in Table 3 shows that at the beginning of the analyzed period, depreciable bonds traded in the subfederal bonds segment, on average, were characterized by a rather large number of face value repayments (5.01) The repayment of these bonds by face value were conducted fairly evenly (the maximum payment exceeded the minimum payment on average 2.51 times) while with respect to periods between the face value portions' repayments there was much more significant difference between the maximum and minimum indicators (5.70 times).

The parameters of the most common (in frequency) model of the structure of fulfillment of bond issuers' obligations differed from the average parameters to the smaller level for the entire sub-segment: it was characterized by 4 repayments of the face value, and the values?? of the depreciable bond issue repayment uniformity coefficients at the nominal value and by the period between the face value portions' repayments were equal to 1.96 and 5.40, respectively.

The deterioration of the bond market situation at the end 
TABLE III

DISCRETE GROUPING OF DEPRECIABLE SUBFEDERAL BONDS ISSUES BY THE NUMBER OF FACE VALUE REPAYMENTS AS OF JANUARY 1, 2018

\begin{tabular}{cccc}
\hline $\begin{array}{c}\text { The number of } \\
\text { bonds face } \\
\text { value repayments }\end{array}$ & $\begin{array}{c}\text { The number of } \\
\text { circulating bond } \\
\text { issues, pcs. }\end{array}$ & $\begin{array}{c}\text { The average value } \\
\text { depreciable bond } \\
\text { issue repayment } \\
\text { uniformity coefficient } \\
\text { at the face value }\end{array}$ & $\begin{array}{c}\text { The average value of the } \\
\text { of the depreciable bond issue } \\
\text { repayment uniformity coefficient } \\
\text { with respect to periods between } \\
\text { the face value portions' repayments }\end{array}$ \\
\hline 2 & 3 & 8.00 & 9.34 \\
3 & 23 & 2.40 & 4.24 \\
4 & 26 & 1.96 & 5.40 \\
6 & 21 & 2.56 & 7.03 \\
7 & 14 & 2.73 & 5.03 \\
8 & 12 & 2.46 & 10.67 \\
9 & 6 & 1.50 & 8.84 \\
10 & 4 & 3.13 & 4.02 \\
The average value of the indicator & 2 & 1.00 & $\mathbf{5 . 7 0}$ \\
\hline
\end{tabular}

of 2018 led to changes in the existing models of the structure of depreciable bonds issuer' obligations fulfillment, however, in terms of the scale, these changes were not fundamental (Table IV)

As the consequences of adverse changes in the market environment, on average we can indicate an increase in the average number of depreciable bonds nominal value repayments by $2.25 \%$ (from 5.01 to 5.12 ), while the depreciable bond issue repayment uniformity coefficient at the face value reduced by $2.73 \%$, (from 2.51 to 2.44 ) and the depreciable bond issue repayment uniformity coefficient with respect to periods between the face value portions' repayments increased by $1.23 \%$ (from 5.70 to 5.77 ). In relation to the most common (in frequency) model of the structure of depreciable bonds issuers' obligations fulfillment, the indicated trends appeared more clearly: while the number of face value repayments did not change (4 repayments), the depreciable bond issue repayment uniformity coefficient at the nominal value decreased by $12.75 \%$ (from 1.96 to 1.71 ) in this group, and the depreciable bond issue repayment uniformity coefficient with respect to periods between the face value portions' repayments increased by $2.43 \%$ (from 5.40 to 5.53 ).

\section{CONCLUSIONS}

Based on the results of the study, the following conclusions can be formulated:

1) throughout the entire period under review, the probability of successful depreciable bond issues placement in the subfederal segment remained at a high level for bond issues with a nominal value of no more than 30.0 billion rubles and a maturity of no more than 3650 days;

2) deterioration of the bond market environment (both external and internal) did not lead to significant changes in the structure of the bond issuers' obligations fulfillment by the end of the reporting period (the average number of repayments of the depreciable bonds nominal value increased by $2.25 \%$ (from 5.01 to 5.12 ); the depreciable bond issue repayment uniformity coefficient at the face value decreased by $2.73 \%$ (from 2.51 to 2.44 ); the depreciable bond issue repayment uniformity coefficient with respect to periods between the face value portions' repayments increased by $1.23 \%$ (from 5.70 to 5.77 );

3) During the period under review, the most common model for the bond issuers' obligations performance (in frequency) was a model involving 4 repayments of the depreciable bonds nominal value, with respect to which the above trends were more clearly observed (the depreciable bond issue repayment uniformity coefficient at the face value decreased by $12.75 \%$ (from 1.96 to 1.71 ); the depreciable bond issue repayment uniformity coefficient with respect to periods between the face value portions' repayments increased by $12.43 \%$ (from 5.40 to $5.53))$. 
TABLE IV

DISCRETE GROUPING OF DEPRECIABLE SUBFEDERAL BONDS ISSUES BY THE NUMBER OF FACE VALUE REPAYMENTS AS OF JANUARY 1, 2019

\begin{tabular}{cccc}
\hline $\begin{array}{c}\text { The number of } \\
\text { bonds face } \\
\text { value repayments }\end{array}$ & $\begin{array}{c}\text { The number } \\
\text { of circulating } \\
\text { bond issues, pcs. }\end{array}$ & $\begin{array}{c}\text { The average value } \\
\text { of the depreciable } \\
\text { bond issue } \\
\text { repayment uniformity } \\
\text { coefficient at } \\
\text { the face value }\end{array}$ & $\begin{array}{c}\text { The average value } \\
\text { of the depreciable } \\
\text { bond issue repayment } \\
\text { respect to periods between } \\
\text { the face value } \\
\text { portions' repayments }\end{array}$ \\
\hline 2 & 3 & 8.00 & 9.34 \\
3 & 17 & 2.09 & 4.81 \\
4 & 26 & 1.71 & 5.53 \\
5 & 21 & 2.62 & 3.55 \\
7 & 16 & 2.59 & 7.68 \\
8 & 12 & 2.67 & 4.10 \\
9 & 7 & 1.79 & 9.21 \\
10 & 4 & 2.63 & 3.21 \\
The average value of the indicator & 1 & 1.00 & $\mathbf{5 . 7 7}$ \\
\hline
\end{tabular}

\section{REFERENCES}

[1] F. Fabozzi: Bond Markets, Analysis and Strategies". Prentice Hall, Boston, 8nd ed., 2013

[2] S. Boubaker, D.K. Nguyen, V. Piljak, A. Savvides: Financial development, government bond returns, and stability: International evidence". Journal of International Financial Markets, Institutions and Money, vol. 61(C), pp. 81-96, 2019

[3] A. Zaremba, T. Schabek: Seasonality in government bond returns and factor premia". Research in International Business and Finance, vol. 41(C), pp. 292-302, 2017

[4] S. Valseth: Price discovery in government bond markets". Journal of Financial Markets, vol. 16(1), pp. 127-151, 2013

[5] S. Sola, G. Palomba: Sub-nationals' risk premia in fiscal federations: Fiscal performance and institutional design". Journal of International Money and Finance, vol. 63(C), pp. 165-187, 2016

[6] A. V. Yakunina, Yu. V. Semernina: To the issue of classification of bond". Finance and credit, vol. 48(528), pp. 2-12, 2012

[7] E. V. Solovova: Classification of types of public debt and credit". Actual problems of Russian law, vol. 3, pp. 64-72, 2012

[8] P. A. Lashevsky: Classification of infrastructure bonds". Theory and practice of social development, vol. 10, pp. 381-383, 2013

[9] A. A. Shcherbakov: The economic nature and classification of sub-federal bonds". Financial analytics: problems and solutions, vol. 39(225), pp. 5568,2014
[10] A. N. Kiryushkina: Government securities of the constituent entities of the Russian Federation". Bulletin of the Nizhny Novgorod State Engineering and Economic University, vol. 12(67), pp. 145-153, 2016

[11] N. F. Korobov, A. A. Beloglazov: Management of a portfolio of corporate bonds". Bulletin of the Taganrog Institute of Management and Economics, vol. 2, pp. 28-30, 2005

[12] A. A. Ponomarev: Optimization of return on investment portfolio of sub-federal bonds". Bulletin of the Russian State Pedagogical University named after A. I. Herzen, vol. 24, pp. 69-72, 2007

[13] L. V. Sturikova, A. A. Ayupov: Economic basis for the formation and management of a portfolio of bonds of non-state pension funds and insurance companies". Bulletin of Kazan Technological University, vol. 6,pp. 275-279, 2008

[14] O. I. Rekundal: Analysis of the investment attractiveness of sub-federal bonds in the formation of a portfolio of pension savings". Bulletin of Tomsk State University, vol. 360, pp. 140-142, 2012

[15] I. R. Baybekov: Investment strategies of commercial banks in the bond market in Financial analytics: problems and solutions", vol. 37(175), pp. $31-38,2013$

[16] Internet project RusBonds" of the news agency Finmarket". [Online]. Available: https://www.rusbonds.ru/srchsimple.asp 